\title{
Peran Fitur Live Instagram Sebagai Media Transaksi Dalam Membangun Kepercayaan Konsumen
}

\author{
Thoby Darmawan ${ }^{1}$, Titin Suhartini ${ }^{2}$ \\ ${ }^{1,2}$ Departemen Ilmu Komunikasi, Universitas Adhirajasa Reswara Sanjaya, Jalan Sekolah \\ Internasional No.1-2 Bandung, Indonesia. \\ Email:Thobydarmawan@gmail.com
}

\begin{abstract}
Indonesia is currently battling COVID-19. The impact of COVID-19 will not only affect the health sector but also affect the economic sector. From this situation, UMKM entrepreneurs must make efforts to adjust so that the business continues to run in this difficult situation. One way to do this is by switching the sales system to online by Instagram users "Riul Market". Based on this phenomenon, the purpose of this study is to find out the experience of informants regarding the role of the live Instagram feature as a transaction medium during the pandemic. The informants in question are the owners and consumers of the "Riul Market" Instagram account. To answer the research objectives, the researcher used a phenomenological study with a qualitative approach. The phenomenological study focuses on examining the role of the "Riul Market" Instagram live feature as a transaction medium in building consumer trust during the pandemic based on the experience of the research subject. The results of this study indicate that to build trust in the media "Riul Market" brings the original owner at the time of the right to the identity of the store even through online provision. In addition, building trust between the "Riul Market" and the buyer must always be open at the time of bargaining, and transactions are carried out so that there is no fraud on both sides, as a form of flow between the two that can be trusted properly.
\end{abstract}

Keywords: COVID-19, Phenomenology, The Role of Instagram, UMKM

\begin{abstract}
Indonesia hingga saat ini sedang berjuang melawan COVID-19. Dampak yang ditimbulkan dari adanya COVID-19 tidak hanya berpengaruh pada sektor kesehatan tetapi juga berpengaruh pada sektor perekonomian. Dari situasi tersebut membuat pengusaha UMKM harus melakukan usaha untuk beradaptasi agar usahanya tetap berjalan di situasi yang sulit tersebut. Salah satu cara yang dilakukan dengan beralihnya penjualan ke sistem online yang dilakukan oleh pengguna Instagram "Riul Market". Berdasarkan fenomena tersebut, maka tujuan penelitian ini adalah untuk mengetahui pengalaman informan terkait peran fitur live Instagram sebagai media transaksi di masa pandemi. Informan yang dimaksud adalah pemilik dan konsumen dari akun Instagram "Riul Market". Untuk menjawab tujuan penelitian, peneliti menggunakan studi fenomenologi dengan pendekatan kualitatif. Studi fenomenologi fokus mengkaji peran fitur live Instagram "Riul Market" sebagai media transaksi dalam membangun kepercayaan konsumen dimasa pandemic berdasarkan pengalaman dari subjek penelitian. Hasil penelitian ini menunjukan bahwa untuk membangun kepercayaan di media sosial "Riul Market" membawa identitas asli pemilik pada saat live dengan mencantumkan alamat dari tokonya meskipun melalui online penyediaannya. Selain itu membangun kepercayaan antara "Riul Market" dan pembeli harus selalu terbuka pada saat tawar menawar, dan transaksi dilakukan sehingga tidak tercipta unsur penipuan di kedua belah pihak, sebagai wujud arus komunikasi antara keduanya dapat dipercaya dengan baik.
\end{abstract}

Kata kunci : COVID-19, Fenomenologi, Peran Instagram, UMKM

\section{A. PENDAhuluan}

Pada saat ini, teknologi komunikasi merupakan hal yang penting dalam kehidupan sehari hari. Ditandai dengan semakin besarnya kebutuhan akan informasi yang tidak dibatasi oleh ruang 
dan waktu sehingga menimbulkan pengaruh yang sangat signifikan pada berbagai aspek dari kehidupan manusia. Teknologi komunikasi yang memiliki produk nyata salah satunya media, yang telah menjadi komoditas utama yang dibutuhkan oleh manusia setiap harinya (Yusuf, 2017).

Media sosial adalah sarana untuk saling membagi pemikiran, pandangan, bekerja sama dan berkolaborasi untuk menciptakan kreasi, berpikir, berdebat, mencari teman baru, mencari pasangan, dan membangun sebuah komunitas (Yusuf, 2017). Intinya, menggunakan sosial media membuat individu bisa menunjukan dirinya yang sebenarnya. Selain kecepatan informasi yang bisa diakses bahkan dalam hitungan detik, menjadi diri sendiri dalam sosial media merupakan salah satu penyebab media sosial itu berkembang pesat. Tidak terkecuali, keinginan untuk aktualisasi diri dan kebutuhan menciptakan personal branding.

Kata media sosial sudah sudah tidak asing bagi masyarakat indonesia, pengguna sosial media di indonesia terlihat semakin melonjak. Bagi sebagian masyarakat, merasakan seolah ada yang aneh atau kurang jika satu hari saja tidak berkunjung ke akun sosial medianya, hanya sekedar melihat tren yang sedang terjadi atau untuk membuat status di sosial media (Suhandi, 2016). Dengan adanya situs-situs pertemanan di media sosial yang kian populer oleh jutaan penduduk dunia ternyata juga dapat membuat pergeseran akan nilai-nilai sosial dalam masyarakat, terlebih pada kaum remaja. Media sosial telah menjadi bagian dari pengalaman perkembangan tumbuh kembangnya remaja hingga dewasa (Mahendra, 2017)

Sosial media merupakan media yang dirancang untuk memudahkan dalam berinteraksi sosial yang bersifat dua arah atau interaktif. Media sosial yang berlandaskan pada teknologi internet yang membuat perubahan pada pola penyebaran informasi dari yang awalnya bersifat satu ke banyak khalayak menjadi banyak khalayak ke banyak khalayak (Kurniawan, 2017). Unsur utama yang terdapat pada media sosial yaitu media sosial melibatkan saluran sosial yang berbeda dari yang lain dan melalui online menjadi saluran utama media sosial berubah dari waktu ke waktu, artinya media sosial terus berkembang. Media sosial merupakan partisipatif. "Penonton" dianggap kreatif sehingga dapat memberikan komentar (Fadhillah, 2016). Teknologi Web 2.0, merupakan teknologi generasi kedua layanan internet. Kehadiran teknologi internet dan sosial media yang dilakukan untuk tujuan menggerakkan massa dalam perubahan sosial, yang dapat diamati dengan menggunakan teori AIDA yang dikemukakan oleh Kotler dan Keller. AIDA (Attention, Interest, Desire, Action) adalah formula yang sering dipakai untuk membantu perencanaan suatu iklan secara menyeluruh, dan formula itu dapat diterapkan pada suatu iklan. Perencanaan ini yang terdiri atas (Attention), membuat ketertarikan produk (Interest), membuat keinginan untuk memiliki produk (Desire), dan mengajak pelanggan untuk melakukan tindakan dalam pembelian produk (Action) (Yudha, 2020). Model AIDA (Attention, Interest, Desire, Action) akan memperjelas konsep perubahan, sikap, dan perilaku dalam kaitannya dengan sebuah kerangka tindakan. Banyaknya pengguna dari Instagram menjadi hal strategis bagi para 
pebisnis untuk memasarkan dan menjual produk, hanya dengan cara membagikan foto dalam waktu beberapa menit saja, produk yang ditawarkan dapat dilihat oleh seluruh pengguna akun Instagram tanpa harus mengeluarkan banyak biaya dan tenaga. Selain dengan praktisnya media sosial tersebut, Instagram kini menjadi aplikasi sosial media yang populer oleh banyak orang (Kusumawardani et al., 2019). Faktanya untuk saat ini terbukti dengan pengguna aplikasi Instagram di Indonesia yang mencapai 400 juta pengguna aktif berdasarkan data dari Asosiasi Penyelenggara Jaringan Internet Indonesia (APJII) pada tahun 2016 (Fatmawati, 2018)

Aplikasi Instagram sudah menjadi sarana untuk menyiarkan informasi dengan mudah dan sangat cepat, seperti dalam tampilan gambar atau foto yang berupa mengelola foto, mengedit foto, dan berbagi (Share) ke jejaring sosial yang lain. Para pengguna dapat saja mengambil foto lewat perangkat nya mengedit-nya lalu membagikan-nya disertakan caption yang ingin dan sesuka hati untuk dibagikan ke banyak orang yang juga menggunakan Instagram tersebut. (Dimyati, 2019) Secara khusus, Instagram memiliki beberapa fitur-fitur yang dapat bagi beberapa pelaku bisnis pada era sekarang antara lain Live Streaming yang sama halnya seperti teleconference yang memudahkan interaksi penjual. Juga fitur Post Feed yang memungkinkan penjual untuk melakukan penyajian ulang barang yang akan dalam kondisi persediaan yang masih ada. Dengan mengadaptasi Aplikasi Instagram sebagai aplikasi media dalam menjual barang berupa pakaian melalui sistem lelang. (Veygid et al., 2020) Jual beli lelang dalam fiqh muamalah disebut Bai' imuzayyadah atau yang lebih terkenal dengan jual beli lelang merupakan suatu bentuk penawar barang dagangan di tengah-tengah orang banyak dan di keramaian, kemudian para pembeli saling menawar dengan harga yang lebih tinggi sampai pada harga yang paling tinggi dari salah satu pembeli, lalu terjadilah akad dan pembeli tersebut mengambil barang dari penjual (Warid, 2020). Sejak diluncurkan, Instagram telah menambahkan banyak fitur yang menguntungkan pemasar atau pelaku bisnis, baik fitur iklan berbayar maupun posting organik. beberapa fitur dan fungsi Instagram yang paling penting untuk bisnis berupa Instagram Video, Instagram Live Video, IGTV, Instagram Stories, Tag Belanja (Lararenjana, 2021)

Usaha Mikro Kecil dan Menengah atau yang dikenal dengan istilah UMKM diakui sebagai salah satu penyumbang kontribusi bagi perekonomian nasional Indonesia, selain itu UMKM juga disebut sebagai salah satu penopang pertumbuhan ekonomi di Indonesia. Kontribusi UMKM terhadap pertumbuhan ekonomi dalam negeri mencapai 60 persen. Bahkan sektor UMKM menyerap 97 persen tenaga kerja produktif Indonesia dan berperan sebagai penopang ekonomi nasional di saat krisis (Putra, 2018). Dukungan akan pengembangan UMKM di daerah diharapkan dapat meningkatkan pertumbuhan ekonomi, menambah lapangan pekerjaan, dapat mengembangkan ekonomi kerakyatan dan pada akhirnya dapat mensejahterakan masyarakat di berbagai wilayah di Indonesia.

Berdasarkan Undang-Undang Republik Indonesia tentang UMKM Nomor 20 Tahun 2008 pada bab 1, pasal 1 disebutkan bahwa yang dimaksud UMKM merupakan: a) usaha mikro 
adalah usaha produktif milik individu dan atau badan usaha perorangan yang memenuhi syarat usaha mikro sebagaimana diatur dalam Undang-Undang ini, b) usaha kecil adalah usaha ekonomi produktif yang berdiri sendiri, yang dilakukan oleh individu atau badan usaha yang bukan merupakan anak perusahaan atau bukan cabang perusahaan yang dimiliki, dikuasai, atau menjadi bagian baik langsung maupun tidak langsung dari usaha menengah atau usaha besar yang memenuhi syarat usaha kecil sebagaimana dimaksud dalam Undang-Undang ini. c) usaha menengah adalah usaha ekonomi produktif yang berdiri sendiri, yang dilakukan oleh individu atau badan usaha yang bukan merupakan anak perusahaan atau cabang perusahaan yang dimiliki, dikuasai, atau menjadi bagian baik langsung maupun tidak langsung dengan usaha kecil atau usaha besar dengan jumlah kekayaan bersih atau hasil penjualan tahunan sebagaimana diatur dalam Undang-Undang ini. UMKM memiliki tujuan untuk mengembangkan dan menumbuhkan usahanya dalam rangka membangun perekonomian nasional berdasarkan demokrasi ekonomi yang berkeadilan (Undang-Undang Republik Indonesia Nomor 20 Tahun 2008).

Pengusaha produk dalam negeri menggunakan media internet dengan melakukan advertising, sales promotion, direct marketing, dan personal selling terhadap produk-produk mereka di internet karena dapat memasarkan secara murah dan cepat, Para pengusaha merasakan manfaat yang sangat besar dengan menggunakan media internet dibandingkan secara konvensional karena dapat mengurangi jumlah biaya dan waktu yang dikeluarkan dalam proses penjualan produk lokal (Ahyuna et al., 2013). Dari beberapa tahun terakhir, Indonesia diguncangkan dengan skema beberapa brand local yang bisa di bilang menjadi bangkit di negara indonesia sendiri, brand local menempatkan dirinya untuk lifestyle anak muda sehari hari, baik pakaian maupun sepatu. Sebenarnya Indonesia bukanlah sebuah negara yang kurang mengikuti jaman, karena brand local sendiri pun juga banyak yang udah lama lahir di indonesia, seperti : Absolute 308, Maternal Disaster dan Warior tetapi mungkin pada tahun tahun dulu perkembangan brand local tidak terlalu terlihat perkembangannya seperti sekarang yang kebanyakan para penggemar tersendiri dan eksis dengan produk andalannya. (Fadlil, 2019). Alasan kebangkitan brand local yang mulai dilihat oleh masyarakat karena maraknya brand luar negeri yang palsu sehingga membuat konsumen menjadi berpikir dua kali untuk membeli, terkadang jika membeli produk original pun memiliki pandangan buruk oleh konsumen lain yang beranggapan itu palsu, dari sinilah para konsumen mulai pindah dengan membeli brand local bahkan sekaligus menaikkan eksistensi brand tersebut.

Keberadaan fenomena mengenai keberadaan fitur live Instagram sebagai media transaksi jual-beli pada era sekarang ini tidak luput dari besarnya kaum yang dihuni secara segmentasi oleh rentan usia remaja. Berbagai kemudahan yang ada pada smartphone yang terkoneksi dengan internet mendorong jumlah pengguna smartphone di Indonesia dari tahun ke tahun semakin meningkat. Data dari e-Marketer, di Indonesia pengguna aktif smartphone tumbuh dari 55 juta orang pada tahun 2015 menjadi 100 juta orang pada tahun 2018. Sementara itu, menurut Asosiasi 
Pengguna Jasa Internet Indonesia (APJII) pengguna internet di Indonesia pada tahun 2017 tercatat sebanyak 143 juta. Jumlah ini menempatkan Indonesia berada di posisi empat dunia setelah China, India dan Amerika dalam hal pengguna internet. (Rahmayani, 2018)

Berdasarkan data tersebut, APJII juga menyatakan bahwa pengguna internet ternyata didominasi oleh usia 13-18 tahun dengan tingkat penetrasi yang mencapai 75,50 persen. Dari konsep, pada rentang usia 13-18 tahun termasuk dalam kategori remaja. Dimana remaja pada saat ini dikategorikan sebagai Generasi Z, yaitu mereka yang lahir pada tahun 1995-2010. Tidak dapat dipungkiri bahwa Generasi $\mathrm{Z}$ tersebut sejak kecil mereka sudah terbiasa dan sudah mengenal dengan berbagai bentuk gadget. Selain itu, remaja Generasi Z juga lahir dan tumbuh pada saat internet sudah jauh berkembang daripada generasi sebelumnya. Hal ini menyebabkan Generasi Z telah melek internet dari semenjak mereka lahir. Hal ini secara langsung telah merubah sistem ekologi pada remaja era revolusi industri 4.0 ini. (Adiansah et al., 2019)

\section{B. METODE}

Penelitian ini fokus mengkaji peran fitur live Instagram "Ruil Market" sebagai media transaksi dalam membangun kepercayaan konsumen di masa pandemi. Tujuan penelitian ini untuk membangun pengalaman tersebut sehingga terjadinya konsensus bersama antar individu tentang peran fitur live instagram sebagai media transaksi dalam membangun kepercayaan konsumen. Terkait dengan tujuan penelitian ini maka studi fenomenologi dengan pendekatan kualitatif dinilai relevan dengan skema penelitian. Fenomenologi sebagai studi menjelaskan bahwa tiap realitas terbentuk karena adanya pemaknaan atas pengalaman sama yang dialami tiap orang atau individu. Pengalaman tersebut dilatarbelakangi oleh motif-motif yang mendorong individu berperilaku (Nindito, 2013). Dunia pemaknaan terhadap pengalaman merupakan hakikat dari paradigma konstruktivis. Paradigma ini memandang bahwa tiap fenomena dibangun, dan disepakati karena adanya konstruksi bersama sehingga membangun kesepakatan bersama (Hidayat et al., 2018).

Teknik pengumpulan data menggunakan wawancara online. Teknik ini dilakukan menyusul masih diberlakukannya kebijakan pemberlakuan pembatasan kegiatan masyarakat (PPKM). Wawancara melibatkan pemilik, dan konsumen dari "Riul Market". Pemilihan informan menggunakan teknik purposive dengan memperhatikan kriteria. Adapun kriteria informan adalah mereka yang mengikuti akun "Riul Market". Selain wawancara, teknik pengumpulan data juga melalui telaah data dari berbagai sumber, seperti situs online, dan artikel hasil penelitian sebelumnya terkait COVID-19.

Analisis data dilakukan melalui tiga tahapan, meliputi konstruk data pertama, konstruk data kedua, dan konstruk data ketiga (Yayu et al., 2019). Konstruk data pertama peneliti membuat transkrip hasil wawancara dengan informan terkait peran fitur live Instagram sebagai media dalam mebangun kepercayaan pelanggan di masa pandemi. Tahapan pertama ini sering pula 
disebut dengan istilah reduksi data atau menyeleksi data sesuai dengan tujuan penelitian. Tahapan konstruk data kedua, peneliti memilah atau mengklasifikasikan data sesuai dengan kebutuhan tiap pertanyaan penelitian terkait peran fitur live Instagram sebagai media dalam mebangun kepercayaan pelanggan di masa pandemi. Bentuk dari konstruk data kedua ini berupa tabel atau matriks data. Tahapan ini juga lazim disebut tahapan display data. Display artinya menyajikan data hasil penelitian terkait peran fitur live Instagram sebagai media dalam mebangun kepercayaan pelanggan di masa pandemi. Display data mengacu pada pembagian pertanyaan penelitian yang telah ditentukan sebelumnya. Display data biasanya disajikan pada hasil penelitian. Tahapan konstruk data ketiga yakni membuat analisis data. Analisis berdasarkan data dan penjelasan teori yang relevan dengan hasil penelitian. Tahapan ini sering pula disebut dengan tahapan penarikan kesimpulan data. Tahapan ini disajikan pada bagian pembahasan hasil penelitian (Yudhaswara \& Hidayat, 2020).

\section{HASIL DAN PEMBAHASAN}

Pandemik COVID-19 membawa perubahan dalam hal apapun, karena memberikan ancaman kesehatan dan keselamatan kerja dalam beraktivitas maupun pekerjaan. Aturan Pembatasan Sosial Skala Besar (PSBB) mulai diterapkan pada awal bulan April lalu di sejumlah kota besar di Indonesia sebagai salah satu upaya penanganan persebaran virus. Selain membuat kebijakan dan penerapan PSBB, sosialisasi protokol kesehatan juga terus dilakukan oleh pemerintah daerah maupun pemerintah pusat untuk menekan penyebaran dan angka positif tertularnya COVID-19. Kondisi ini berdampak drastis kepada kegiatan sosial, rutinitas dan gaya hidup masyarakat, khususnya di daerah PSBB dan zona merah COVID-19.

Keberadan ini tentunya menyulitkan dari sektor ekonomi salah satunya bisnis di ranah UMKM yang memang sejatinya mereka melakukan bisnis dengan jalan sendiri dan bermodalkan kecil, pada penelitian ini penulis memang akan membahas ranah bisnis di "Riul Market" salah satu took online baju dengan mengandalkan barang dagangan nya yang dalam kondisi bekas namun layak jual, atau lebih dikenal dengan istilah Thrifting Brand. "Riul Market" secara metode berjualan memang menggunakan bisnis online di e-commerce, namun yang unik dari keberadaan cara berjualannya dengan menggunakan fitur live yang ada di sosial media Instagram sebagau bentuk interaksi penjual dan pembelinya.

Kebiasaan baru (New Normal) menyesuaikan sudut pandang dari beberapa kepentingan dan institusi. Secara umum new normal merupakan sebuah cara atau tatanan baru dalam menjalani kehidupan dan aktivitas sehari-hari. Menurut pakar kesehatan dan dilihat dari perspektif kesehatan, agar suatu daerah atau negara dapat menerapkan new normal harus memenuhi beberapa kriteria persyaratan, antara lain daerah tersebut sudah terbukti mengalami perlambatan kasus penyebaran virus, sudah diberlakukannya PSBB secara maksimal, kondisi masyarakat yang siap dan mampu memenuhi kebutuhan daya tahan tubuh serta tersedianya infrastruktur 
yang memadai untuk mendukung aktivitas sehari-hari. Dari sudut pandang sosial, new normal merubah perilaku masyarakat agar lebih waspada dan mengurangi kontak langsung seperti jabat tangan dan berkumpul dengan teman, saudara dan orang lain. Sedangkan dari sisi ekonomi dan bisnis, new normal menggeser bisnis model menjadi serba digital dan bergantung pada teknologi. Sedang pemerintah Indonesia mendefinisikan new normal sebagai membudayakan hidup bersih dan sehat dengan rajin melakukan cuci tangan, menggunakan masker, menjaga jarak dan menghindari kerumunan masyarakat.

Dari kondisi ini "Riul Market" akhirnya memang mengawali bisnisnya dengan menggunakan media sosial sebagai penunjang bisnisnya, karena keberadaan pasar sekarang di era digital ini yang memang mayoritas memilih ranah bisnis melalui media online dinilai tidak terlalu memakan resiko yang besar. Menurut American Marketing Association pemasaran adalah proses perencanaan dan pelaksanaan konsep, penetapan harga, promosi, dan distribusi ide, produk, dan jasa untuk menciptakan pertukaran yang memuaskan tujuan individu perorangan dan perusahaan. Komunikasi merupakan elemen yang sangat penting dalam menciptakan pertukaran tersebut, sehingga komunikasi memiliki peranan yang sangat penting dalam dunia pemasaran.

Beradaptasi dengan situasi memang pada akhirnya menjadi solusi untuk tetap bertahan di dalam bisnis pada era pandemi sekarang, hal ini serupa dengan gaya bisnis "Riul Market" yang menggunakan layanan fitur live Instagram untuk menunjang bisnisnya, dengan cara itu lebih efektif dan efisien untuk dapat tetap memberikan pelayan bisnis yang dilakukan oleh "Riul Market". Media bukan hanya suatu instrumen informasi atau cara untuk mencapai sebuah ketertarikan diri, namun menyatukan kita dalam beberapa bentuk masyarakat dan memberi kita rasa saling memiliki. Istilah new media lambat laun mulai ramai dan dikenal pada tahun 1980. Dimana dunia media dan komunikasi mulai berbeda karena kemunculan media baru ini, tidak ada batasan pada satu sektor atau elemen tertentu.

Dalam pengertian ini, munculnya "media baru" sebagai semacam fenomena yang dilihat dari sisi sosial teknologi dan perubahan budaya. Perkembangan teknologi informasi dan komunikasi tidak saja merubah media tapi juga merubah kehidupan sosial dan budaya sebagai perubah bisnis UMKM di era digital. Berdasarkan Undang-Undang Republik Indonesia tentang UMKM Nomor 20 Tahun 2008 pada bab 1, pasal 1 disebutkan bahwa yang dimaksud UMKM merupakan: a) usaha mikro adalah usaha produktif milik individu dan atau badan usaha perorangan yang memenuhi syarat usaha mikro sebagaimana diatur dalam Undang-Undang ini, b) usaha kecil adalah usaha ekonomi produktif yang berdiri sendiri, yang dilakukan oleh individu atau badan usaha yang bukan merupakan anak perusahaan atau bukan cabang perusahaan yang dimiliki, dikuasai, atau menjadi bagian baik langsung maupun tidak langsung dari usaha menengah atau usaha besar yang memenuhi syarat usaha kecil sebagaimana dimaksud dalam Undang-Undang ini. c) usaha menengah adalah usaha ekonomi produktif yang berdiri sendiri, yang dilakukan oleh individu atau badan usaha yang bukan merupakan anak perusahaan atau cabang perusahaan 
yang dimiliki, dikuasai, atau menjadi bagian baik langsung maupun tidak langsung dengan usaha kecil atau usaha besar dengan jumlah kekayaan bersih atau hasil penjualan tahunan sebagaimana diatur dalam Undang-Undang ini. (Putra, 2018)

Media sosial merupakan sebuah media online yang para penggunanya dapat dengan mudah berbagi, berpartisipasi, dan menciptakan isi meliputi wiki, forum, blog, jejaring sosial, dan dunia virtual (Cahyono, 2016). Blog merupakan bentuk media sosial yang umum digunakan oleh masyarakat di seluruh dunia. Andreas Kaplan dan Michael Haenlein mendefinisikan media sosial sebagai "sebuah kelompok aplikasi berbasis internet yang membangun di atas dasar ideologi dan teknologi Web, dan yang memungkinkan penciptaan dan pertukaran". Tak bisa kita pungkiri di era globalisasi ini telah membawa perubahan yang begitu besar terhadap pola pikir dan gaya hidup manusia, seakan ditantang untuk beradaptasi secara cepat terhadap perubahan zaman yang begitu mengejutkan, majunya teknologi dan ilmu pengetahuan membawa kehidupan manusia ke era yang tak terbatas, jangkauan semakin luas, apapun bisa di dapatkan saat ini, hanya dengan duduk didepan layar komputer atau laptop, manusia begitu mudah mendapatkan apa yang mereka mau, hal ini telah mengakibatkan terjadinya instanisasi kebutuhan, sehingga hal ini secara tidak sadar telah merubah pola kebutuhan manusia. (Ainiyah, 2017)

Membentuk kepercayaan adalah bentuk dari suatu bisnis diantara kedua belah pihak dapat berjalan dengan baik, seperti "Riul Market" yang menggunakan fitur live Instagram untuk dapat membentuk kepercayaan kepada konsumennya. Kepercayaan yang dibuat oleh "Riul Market" memang mengharuskan kepada konsumen juga membuat kesepakatan ketika sudah melakukan persetujuan terhadap satu barang, melalui media juga kepercayaan tersebut dapat dibentuk, karena pada akhirnya penulis akan mengaitkan keberadaan itu dengan konteks teori determinisme yang dimana teori ini dikemukakan oleh Marshall McLuhan dalam buku yaitu Understanding Media, ia menulis tentang pengaruh teknologi. Ide dasar teori ini adalah perubahan yang terjadi dalam berkomunikasi akan membentuk keberadaan manusia itu sendiri. teknologi akan berpengaruh terhadap pola hidup dalam berfikir, berperilaku dalam masyarakat dan menjadi manusia yang lebih kekinian mengikuti zaman (Meisyaroh, 2013). Seperti dalam temuan dari penelitian yang dilakukan oleh budi bahwa PT. Anugrah Wajar Pria (AWP) menggunakan Instagram untuk membuat iklan produknya, Hal tersebut dilakukan untuk membuat brand awareness pada produk pisau cukur Banner dari produk mereka, selain untuk memasarkan produknya, PT. AWP juga memanfaatkan Instagram untuk mengetahui kepuasan konsumen mereka dari hasil data tersebut dimanfaatkan untuk menganalisis dan membuat strategi mereka kedepannya (Bramasta, 2020). McLuhan berpendapat bahwa teknologi dapat merubah budaya yang dibentuk oleh bagaimana caranya manusia berkomunikasi. Ada beberapa tahap manusia dalam mengenal media komunikasi. Pertama, teknologi dapat merubah kebudayaan. Kedua, jenis-jenis komunikasi dapat membentuk manusia. Ketiga, seperti yang dikatakan McLuhan "Kita membuat peralatan untuk berkomunikasi dan akhirnya peralatan yang 
kita buat untuk berkomunikasi akan membentuk atau mempengaruhi kehidupan kita". (Herawati, 2011)

Teknologi begitu memberikan peranan penting bagi setiap kehidupan manusia. Hampir setiap orang bergantung pada teknologi karena setiap detik mereka menggunakannya. McLuhan menganggap teknologi menjadi sebuah revolusi baru ditengah masyarakat dan media berperan menciptakan dan mengolah budaya. Media menjadi alat yang dapat mengubah gaya hidup masyarakat. Media cetak dan media elektronik adalah salah satu dalam perubahan budaya, karena McLuhan menganggap bahwa media adalah pesan itu sendiri. media merupakan alat untuk memperkuat, memperkeras dan memperluas fungsi dan perasaan manusia. Beberapa sarjana menyebut pemikiran McLuhan mengenai hubungan teknologi, media dan masyarakat ini dengan sebutan Technological Determinism yaitu teknologi yang bersifat determinan (menentukan) dalam membentuk gaya hidup manusia. (Tulasi, 2012)

Perkembangan teknologi saat ini juga sangat mempengaruhi peran media massa, kebebasan media massa dan dukungan dari teknologi tersebut dapat menghadirkan dua kondisi, satu sisi akses informasi yang semakin mudah untuk masyarakat akan meningkatkan kesadaran masyarakat untuk ikut serta dalam penyelenggaraan pemerintahan yang pada akhirnya akan menciptakan kondisi yang demokratis, namun di sisi lainnya adalah kebebasan yang dimaksud tidak diiringi dengan tanggung jawab akan menimbulkan kebebasan yang tidak terarah. Teknologi memfasilitasi proses keterhubungan dalam skala yang lebih besar. Fenomena ini meningkat keterkaitan ekonomi, politik, masyarakat dan budaya dianggap sebagai globalisasi. Media disajikan sebagai alat untuk mempercepat proses ini dan menghilangkan Batasan. (Fauzi, 2020)

\section{PENUTUP}

Penulis akan memaparkan perihal kesimpulan dari hasil penelitian dengan mengacu kepada kajian literatur yang sudah penulis paparkan sebelumnya terhadap fokus penelitian yaitu peran fitur live Instagram "Ruil Market" sebagai media transaksi jual beli dalam membangun kepercayaan konsumen di masa pandemi.

"Riul Market" membentuk informasi dengan melakukan interaksi kepada pembeli pada saat live, dan saat live para pembeli harus menggunakan akun id pribadi untuk dapat respon dari "Riul Market" sehingga informasi penjualan dapat disampaikan. Untuk membangun kepercayaan di media sosial "Riul Market" juga membawa identitas asli pemilik pada saat live dengan mencantumkan alamat dari tokonya meskipun melalui online penyediaannya. Dalam membangun kepercayaan antara "Riul Market" dan pembeli harus selalu terbuka pada saat tawar menawar, dan transaksi dilakukan sehingga tidak ada tercipta unsur penipuan di kedua belah pihak, sebagai wujud arus komunikasi antara keduanya dapat dipercaya dengan baik. 


\section{DAFTAR PUSTAKA}

Adiansah, W., Setiawan, E., Kodaruddin, W. N., \& Wibowo, H. (2019). Person in Environment Remaja Pada Era Revolusi Industri 4.0. Focus : Jurnal Pekerjaan Sosial, 2(1), 47. https://doi.org/10.24198/focus.v2i1.23118

Ahyuna, Hamzah, M. D., \& HM, M. N. (2013). Pemanfaatan Internet Sebagai Media Promosi Pemasaran Produk Lokal Oleh Kalangan Usaha Di Kota Makassar. Jurnal Komunikasi KAREBA, 2(1), 30-40. http://journal.unhas.ac.id/index.php/kareba/article/view/346

Ainiyah, N. (2017). Fenomena Komunikasi melalui Media Sosial di Kalangan Remaja. Jurnal Askopis, 1(2), 135-147. https://doi.org/10.32494/ja.v1i2.35

Bramasta, A. B. (2020). Analisis Strategi Online Consumer Relationship Management Pada Produk Pisau Cukur Banner. Jurnal Media Dan Komunikasi, 01(1), 55-67. https://ejournal.unair.ac.id/MEDKOM/article/viewFile/22927/12572

Cahyono, A. S. (2016). Pengaruh Media Sosial Terhadap Perubahan Sosial Masyarakat Di Indonesia. Jurnal Ilmu Sosial \& Ilmu Politik Diterbitkan Oleh Fakultas Ilmu Sosial \& Politik, Universitas Tulungagung, 9(1), 140-157. http://www.jurnalunita.org/index.php/publiciana/article/download/79/73

Dimyati, W. (2019). Presentasi Diri Tri Yoana Rahma Sebagai Selebgram Fashion Urban. Universitas Adhirajasa Reswara Sanjaya.

Fadhillah, M. B. (2016). Pengaruh Intensitas Mengakses Media Sosial (Twitter) Terhadap Kualitas Komunikasi Keluarga Di SMP Putra 1 Jakarta. Universitas Negeri Jakarta.

Fadlil, A. (2019). Kebangkitan Local Pride di Indonesia. Articel.

Fatmawati, S. (2018). Pengaruh Iklan Model AIDA (attention, interest,desire,action) Terhadap Keputusan Pembelian Di Shopee Indonesia Pada Mahasiswa FISIP UNISKA MAB. Journal of Chemical Information and Modeling, 11.

Fauzi, M. (2020). Peran Media Massa Dalam Pendidikan Politik Melalui Sosialisasi Politik [Universitas Muhammadiyah Mataram]. http://dx.doi.org/10.1016/j.ndteint.2014.07.001\%0Ahttps://doi.org/10.1016/j.ndteint.2017.1 2.003\%0Ahttp://dx.doi.org/10.1016/j.matdes.2017.02.024

Herawati, E. (2011). Komunikasi Dalam Era Teknologi Komunikasi Informasi. Humaniora.

Hidayat, D., Kuswarno, E., Zubair, F., \& Hafiar, H. (2018). Public Relations Communication Behavior Through a Local-Wisdom Approach: The Findings of Public Relations Components Via Ethnography as Methodology. Malaysian Journal of Communication, 34(3), 56-72.

Kurniawan, P. (2017). Pemanfaatan Media Sosial Instagram Sebagai Komunikasi Pemasaran Modern Pada Batik Burneh Puguh Kurniawan Universitas Trunojoyo Madura. Manajemen Fakultas Ekonomi Dan Bisnis Universitas Trunojoyo Madura, 11(2), 219. http://journal.trunojoyo.ac.id/kompetensi/article/view/3533

Kusumawardani, N. A., Erawan, E., \& Purwanti, S. (2019). Persepsi Mahasiswa Tentang Iklan 
Indomie Mie Goreng Aceh Di Youtube Dalam Menimbulkan Minat Beli. EJournal Ilmu Komunikasi, 7(2), 253-264.

Lararenjana, E. (2021). Berikut Fungsi Instagram yang Paling Utama, Bisa untuk Kembangkan Bisnis. Www.Merdeka.Com. https://www.merdeka.com/jatim/berikut-fungsi-instagramyang-paling-utama-bisa-untuk-kembangkan-bisnis-kln.html?page $=4$

Mahendra, B. (2017). Eksistensi Sosial Remaja Dalam Instagram (Sebuah Perspektif Komunikasi). Jurnal Visi Komunikasi, 16(1), 151-160.

Meisyaroh, S. (2013). Determinisme Teknologi Masyarakat Dalam Media Sosial. Jurnal Komunikasi Dan Bisnis, Vol 1(No 1), 36-46.

Nindito, S. (2013). Fenomenologi Alfred Schutz: Studi tentang Konstruksi Makna dan Realitas dalam Ilmu Sosial. Jurnal ILMU KOMUNIKASI, 2(1), 79-95. https://doi.org/10.24002/jik.v2i1.254

Putra, Y. M. (2018a). Pemetaan Penerapan Standar Akuntansi Keuangan Emkm Pada Umkm Di Kota Tangerang Selatan. Jurnal Profita, 11(2), 201. https://doi.org/10.22441/profita.2018.v11.02.004

Putra, Y. M. (2018b). Pemetaan Penerapan Standar Akuntansi Keuangan EMKM Pada UMKM Di Kota Tangerang Selatan. Profita: Komunitas Ilmiah Akuntansi Dan Perpajakan, 11(2), 17.

Rahmayani, I. (2018). Indonesia Raksasa Teknologi Digital Asia. Www.Kominfo.Go.Id. https://kominfo.go.id/content/detail/6095/indonesia-raksasa-teknologi-digitalasia/0/sorotan_media

Suhandi, R. N. (n.d.). Media Sosial Sebagai Gerakan Sosial. Https://Www.Kompasiana.Com/.

Tulasi, D. (2012). Terapan Media Massa Dan Turbulensi Budaya Lokal. Humaniora, 3(1), 135144.

Undang-Undang Republik Indonesia Nomor 20 Tahun 2008, Pub. L. No. NOMOR 20 TAHUN 2008, 31 (2008).

Veygid, A., Aziz, S. M., \& R, W. S. S. (2020). Analis is Fitur dalam Aplikasi Instagram Sebagai Media Pembelajaran Online Mata Pelajaran Biologi untuk Siswa Sekolah Menengah Atas. ALVEOLI: Jurnal Pendidikan Biologi, 1(1), 39-48. https://alveoli.iainjember.ac.id/index.php/alv/article/view/5

Warid, M. A. (2020). Implementasi Lelang Barang Jaminan Di Pegadaian Syariah. Institut Agama Islam (IAIN) Bengkulu.

Yayu, N., Anisti, A., Hidayat, D., \& Suhadi, M. (2019). Pendekatan intercultural communication pada public relations PT Santos dalam membangun komunikasi empati. PRofesi Humas, 4(1), 1-22. https://doi.org/10.24198/prh.v4i1.18626

Yudha, A. T. (2020). Pengaruh Penggunaan New Media Terhadap Citra Merek Dan Minat Beli Pelanggan Pada E-Commerce "TOKOPEDIA" Di Kota Medan [Universitas Sumatra Utara Medan]. https://www.usu.ac.id/id/fakultas.html 
Volume 02 Nomor 01 (2021) 54-65 https://e-journal.unair.ac.id/Medkom

Yudhaswara, R. K., \& Hidayat, D. (2020). Perilaku Selektif Memilih Informasi COVID-19 Di Media Massa. 7.

Yusuf, D. P. (2017). Pengaruh Pengguna Media Sosial Facebook Terhadap Pola Komunikasi Interpersonal Di SDN IV Sudirman Makassar. Universitas Hasanuddin Makassar. 